STRUCTURAL MECHANICS 
Available from the authors of Structural Mechanics

4T STRUMEC

A TEACHING PACKAGE

consisting of

\section{COMPUTER BASED TUTORIALS}

- each tutorial relates to a programme of study in this text

- each tutorial consists of 30 to 50 questions and problems

- each tutorial can be used for self-assessment or examination

- each tutorial gives instant feedback on performance

- these tutorials are highly visual and student friendly in presentation

\section{OVERHEAD TRANSPARENCIES}

- match each programme of study

- ensure a high level of class presentation

TWO TEXT BOOKS

- Structural Mechanics from the Foundations of Engineering Series

- Structural Mechanics from the College Work Out Series

\section{T STRUMEC}

...a comprehensive and integrated package for the teaching of

Structural Mechanics, available for purchase by any

University and College.

For further details write to:

Ray Hulse, Associate Dean, School of the Built Environment, Coventry University, Coventry, CV1 5FB. 


\title{
FOUNDATIONS OF ENGINEERING
}

Series Editor: G. E. Drabble

\section{Structural Mechanics Jack Cain Formerly Senior Course Tutor \\ Civil Engineering Coventry University}

\author{
Ray Hulse \\ Head of Academic Programmes \\ School of The Built Environment \\ Coventry University
}

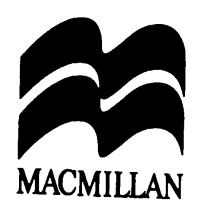


() J. A. Cain and R. Hulse 1990

All rights reserved. No reproduction, copy or transmission of this publication may be made without written permission.

No paragraph of this publication may be reproduced, copied or transmitted save with written permission or in accordance with the provisions of the Copyright, Designs and Patents Act 1988, or under the terms of any licence permitting limited copying issued by the Copyright Licensing Agency, 90 Tottenham Court Road, London WIP 9HE.

Any person who does any unauthorised act in relation to this publication may be liable to criminal prosecution and civil claims for damages.

First published 1990 by

MACMILLAN PRESS LTD

Houndmills, Basingstoke, Hampshire RG21 6XS

and London

Companies and representatives

throughout the world

ISBN 978-0-333-48078-6 ISBN 978-1-349-10542-7 (eBook)

DOI 10.1007/978-1-349-10542-7

A catalogue record for this book is available from the British Library.

$\begin{array}{llllllll}13 & 12 & 11 & 10 & 9 & 8 & 7 & 6\end{array}$

$\begin{array}{lllllll}04 & 03 & 02 & 01 & 00 & 99 & 98\end{array}$

A Solutions Manual is available from the Publishers

ISBN 978-0-333-68790-1 
To Pat and Jean 


\section{FOUNDATIONS OF ENGINEERING SERIES}

\section{J. A. Cain and R. Hulse Structural Mechanics}

G. E. Drabble Dynamics

R. G. Powell Electromagnetism

P. Silvester Electric Circuits

J. Simonson Thermodynamics

M. Widden Fluid Mechanics

\footnotetext{
Series Standing Order

If you would like to receive future titles in this series as they are published, you can make use of our standing order facility. To place a standing order please contact your bookseller or, in case of difficulty, write to us at the address below with your name and address and the name of the series. Please state with which title you wish to begin your standing order. (If you live outside the United Kingdom we may not have the rights for your area, in which case we will forward your order to the publisher concerned.)

Customer Services Department, Macmillan Distribution Ltd

Houndmills, Basingstoke, Hampshire RG21 6XS, England
} 


\section{CONTENTS}

Series Editor's Foreword

viii

Authors' Preface

ix

How to use this book

Programme

1 Revision of the Fundamentals of Statics

1

2 Simple Structures (Loads and Reactions) 27

3 Pin Jointed Frame Structures $\quad 69$

4 Shearing Forces and Bending Moments 99

5 Stress Analysis (Direct Stresses) 137

6 Bending Stresses 163

7 Combined Bending and Direct Stresses 197

8 Shear Stresses $\quad 225$

9 Torsional Stresses 259

10 Stress Transformations and Mohr's Circle of Stress 287

11 Composite Sections $\quad 315$

12 Beam Deflections and Rotations 349

13 Strain Energy 383

14 Virtual Work 407

$\begin{array}{ll}\text { Index } & 435\end{array}$ 


\section{SERIES EDITOR'S FOREWORD}

This series of programmed texts has been written specifically for first year students on degree courses in engineering. Each book covers one of the core subjects required by electrical, mechanical, civil or general engineering students, and the contents have been designed to match the first year requirements of most universities and polytechnics.

The layout of the texts is based on that of the well-known text, Engineering Mathematics by K. Stroud (first published by Macmillan in 1970, and now in its third edition). The remarkable success of this book owes much to the skill of its author, but it also shows that students greatly appreciate a book which aims primarily to help them to learn their chosen subjects at their own pace. The authors of this present series acknowledge their debt to Mr Stroud, and hope that by adapting his style and methods to their own subjects they have produced equally helpful and popular texts.

Before publication of each text the comments of a class of first year students, of some recent engineering graduates and of some lecturers in the field have been obtained. These helped to identify any points which were particularly difficult or obscure to the average reader or which were technically inaccurate or misleading. Subsequent revisions have eliminated the difficulties which were highlighted at this stage, but it is likely that, despite these efforts, a few may have passed unnoticed. For this the authors and publishers apologise, and would welcome criticisms and suggestions from readers.

Readers should bear in mind that mastering any engineering subject requires considerable effort. The aim of these texts is to present the material as simply as possible and in a way which enables students to learn at their own pace, to gain confidence and to check their understanding. The responsibility for learning is, however, still very much their own.

G. E. DRABBLE 


\section{AUTHORS' PREFACE}

This book contains fourteen programmes incorporating material which will be found in most first year undergraduate and HND syllabuses in Strength of Materials and Structural Analysis. The book is intended for use by students of Engineering and Building as a first text in Structural Mechanics as taught in most Polytechnic and University departments of Engineering and Construction.

The aim of the text is to provide a sound understanding of fundamental principles of Structural Mechanics by presenting the principles and concepts involved in a distinctive programmed learning format whereby the student can work and learn at his/her own pace and test his/her understanding by answering a series of carefully constructed questions and graded practical problems.

Although it is assumed that students using the book will have some grasp of elementary mechanics, the first chapter provides useful revision of the basic principles of statics which provide the foundation material for the rest of the book. Subsequent chapters deal with concepts of structural form and types of loading. Techniques for analysing statically determinate pin jointed frame structures and simply supported and cantilevered beams are introduced. The drawing of shear force and bending moment diagrams for beams subjected to different types of loading is given comprehensive coverage.

A number of programmes cover stress analysis including analysis and design of structures subjected to direct, bending, shear or torsional stress. Problems involving combined bending and axial loading are also considered. The analysis of complex stress situations using Mohr's Circle of Stress forms the basis of one complete programme, as does the analysis of composite sections under different stress situations including thermal loading.

Later programmes show how the deflection of statically determinate beams may be calculated using integration techniques, and Strain Energy and Virtual Work methods are introduced as a foundation for further more advanced study.

The book is suitable for general class use and for individual study supported by seminar and/or tutorial work. It is appreciated that the coverage of the text may be a little greater than that required for some courses and that the last few programmes may, in many courses, form part of second year work. This is intentional as the earlier programmes are suitable for use by HND students or those undergraduates on Building Courses where the depth of study of Structural Mechanics may not be so great. Engineering undergraduates will find that most of the text will be required in their first year studies and the more able student, by grasping the subject matter more quickly, will be able to work to the end of the book thereby gaining an early introduction to second year studies.

Throughout the book the emphasis is on student centred learning with the intention of providing the student with a sound grasp of the fundamental principles of Structural 
Mechanics. Although nowadays computers are frequently used to carry out the more routine and/or complex calculations associated with Structural Mechanics, at this level of study it is important that fundamental principles and concepts of structural behaviour are studied and understood. It is only with a sound grasp of basic theory that the student will be able to progress satisfactorily to the study of more advanced concepts of structural behaviour and competently to apply the theories learnt to the design of structures and structural elements.

We are indebted to those who have assisted us in writing this book including the 1988 intake of Building and Civil Engineering students at Coventry Polytechnic who co-operated with us in the testing of the material that forms the basis of this text. With their help we were able to refine the original draft to its present form. Thanks also to the final year Civil Engineering M.Eng. students at Coventry Polytechnic for reading and commenting on parts of the text, and to various reviewers who made useful and constructive comments.

RAY HULSE JACK CAIN 


\section{HOW TO USE THIS BOOK}

This book contains fourteen 'programmes'. Each programme is a self-contained unit of study which deals with one specific topic. However as the later programmes build on material studied in earlier parts of the book, you are advised to work systematically through the text studying the programmes in the given sequence.

You must start at the beginning of and work sequentially through each programme. Every programme is subdivided into a number of short 'frames', each of which contains a limited quantity of information. The frames are designed to enable you to learn at your own pace, and most of them end with a short question or problem for you to tackle. These enable you to test your understanding of the material that you have just studied. The correct answer to each problem is given at the top of the next frame.

To use the book most effectively you should use a piece of paper or card to conceal the next frame until you have answered the given question. You can use the paper for rough working if necessary. Only when you have made a response should you look at the answer. If you have given an incorrect answer you should not proceed until you have found out why you made a mistake. Usually a worked solution or some further explanation will be given immediately below each answer so that you should be able to find where and why you went wrong. If you still cannot understand how to get the correct answer, you should make a note to discuss it with another student or with your tutor.

At the end of and at intermediate stages throughout each programme you will find sets of problems for you to tackle. You must attempt as many of these problems as possible. They are graded in difficulty and will give practice in applying the techniques that you have learnt.

The most important thing to remember is that you should work systematically, sequentially and carefully through the book at whatever pace of learning you find comfortable. Do not miss out any part of any programme, don't 'cheat' by looking at the answers to questions before offering your own solution and do not proceed at any stage until you are satisfied that you have grasped the information in the frame that you have just studied. 